\title{
INSTYTUCJONALIZACJA ZEWNĘTRZNA UNII EUROPEJSKIEJ NA PRZYKŁADZIE AFRYKI SUBSAHARYJSKIEJ
}

\section{Wprowadzenie}

Celem badania jest pokazanie na przykładzie stosunków UE-Afryka Subsaharyjska procesu instytucjonalizacji, rozumianej jako sieć rozwiązań prawnych i instytucjonalnych kształtujących stosunki międzynarodowe. W tym kontekście jest to instrument przyspieszający pewne rozwiązania systemowe, co ma prowadzić do zmian w państwach i regionach nimi objętych. Zmiany te dotyczą reguł oraz zachowań w państwach, do których działania te są kierowane, w tych przypadku Afryki Subsaharyjskiej, a także w tych podmiotach, które je inicjują (UE). Badanie jest próbą pokazania czy i w jakim zakresie deklarowany stopień integracji różnych instrumentów polityki zagranicznej UE pokrywa się z ich rzeczywistą realizacją względem państw afrykańskich.

Proces instytucjonalizacji stosunków z krajami Afryki Subsaharyjskiej jest jednym ze sposobów włączenia ich do głównego nurtu gospodarki światowej, co będzie prowadziło do obopólnych korzyści. Dla państw afrykańskich, ponieważ umożliwi im udział w globalnym systemie, otworzy rynki na eksport ich towarów i przyspieszy restrukturyzację gospodarek i systemów politycznych. Dla UE, ponieważ perspektywa udziału państw afrykańskich w światowym systemie gospodarczym przyczyni się do poprawy ich sytuacji gospodarczej, politycznej i społecznej, a co za tym idzie wpłynie na normalizację kontaktów przez ograniczenie systemu specjalnych preferencji. Oczekuje się, że wzajemne stosunki UE-Afryka oparte zostaną na wzajemnych zobowiązaniach i aktywnym działaniu każdej ze stron. Poza tym UE nie chce być dłużej obarczona odpowiedzialnością „moralną” za rozwój tych państw, co wynika z przeszłości kolonialnej, a więc bliskich więzi historycznych, kulturowych, politycznych i gospodarczych. To już nie bierne traktowanie państw trzecich jako odbiorców określonych form pomocy, ale wspólne podejmowanie decyzji z partnerami dotyczące tego, co im jest potrzebne i jak możemy pomóc w osiąganiu takiego celu. UE jak również inne organizacje międzynarodowe pełnią tu rolę „zewnętrznych 
mentorów", których prosi się o pomoc, bo mają warunki, aby to robić, niemniej jednak to partner decyduje, na ile chce korzystać z tej pomocy i jak ją spożytkuje.

\section{UE-Afryka: początki współpracy}

Stosunki między Unią Europejską i Afryką Subsaharyjską znajdują się obecnie w nowej fazie rozwoju. Powodem jest zmieniająca się rola UE w regionie i na świecie oraz ewolucja stosunków międzynarodowych, których charakterystyczną cechą są pogłębiające się współzależności. Nowy kierunek wzajemnych relacji wyznaczają zmieniające się potrzeby i interesy UE oraz krajów afrykańskich, będące następstwem rozwoju procesów globalizacji i integracji, ale także fragmentacji. Nie bez znaczenia pozostają specjalne więzi łączące państwa afrykańskie z byłymi metropoliami europejskimi z czasów kolonialnych, które bezsprzecznie oddziałują na politykę prowadzoną współcześnie. Ten szczególny typ relacji można określić jako „konglomerat poczucia odpowiedzialności, woli zadośćuczynienia, dążeń wolnorynkowych oraz promowania demokracji i praw człowieka, a jednocześnie świadomości nierozerwalnego funkcjonowania obok siebie i wspólnie, wynikającego z położenia geograficznego". ${ }^{1}$ Realizując nową wizję działania na arenie międzynarodowej, Unia Europejska chce pokazać nowy kierunek zmian w polityce zewnętrznej, gdzie Afryka zajmuje stałe i ważne miejsce. Przede wszystkim wynika to z nieskuteczności poprzedniej polityki, mimo ogromnych nakładów na pomoc rozwojową i specjalne preferencje dla krajów słabo rozwiniętych, a także z powodu nowych graczy na kontynencie afrykańskim, tj. USA i Chin.

Obecne stosunki pomiędzy UE a Afryką regulowane są:

- dla państw należących do grupy Afryki Karaibów i Pacyfiku (AKP) umową z Cotonou (art. 37 stanowi prawną podstawę częściowo już wynegocjowanych Porozumień o Partnerstwie Gospodarczym (Economic Partnership Agreements - EPAs);

- dla państw Afryki Północnej umową Partnerstwo Eurośródziemnomorskie (zapoczątkowane procesem barcelońskim w 1995 roku i rozwinięte w 2008 roku) oraz Europejską Politykę Sąsiedztwa (od 2004 roku);

- dla Republiki Południowej Afryki Porozumieniem o Współpracy w dziedzinie Handlu i Rozwoju z 1999 roku oraz ustaleniami Partnerstwa Strategicznego pomiędzy UE a RPA (z 2006 roku);

1 P. Frankowski, I. Słomczyńska, Unia Europejska-Afryka Subsaharyjska. Uwarunkowania, mechanizmy, efektywność wspótpracy, Wydawnictwo UMCS, Lublin 2011, s. 15. 
- dla całej Afryki Wspólną Strategią Afryki i UE (Joint Africa-EU Strategy - JAES), znanej też jako Partnerstwo Strategiczne pomiędzy UE a Afryką (EU-Africa Strategic Partnership), przyjętą w 2007 roku na II Szczycie UE-Afryka w Lizbonie. ${ }^{2}$

Korzenie polityki UE wobec Afryki sięgają Traktatu rzymskiego (1957), w którym przyjęto zapis o ochronie specjalnych więzi między niektórymi państwami EWG a ich koloniami afrykańskimi. Przede wszystkim chodziło o zabezpieczenie interesów francuskich i zachowanie kontroli nad jej terytoriami zamorskimi. Po przyjęciu do Wspólnot Europejskich Wielkiej Brytanii przedmiotem zainteresowania stała się także od początku lat 70. Brytyjska Wspólnota Narodów (British Commonwealth). ${ }^{3}$ Jednak podczas zimnej wojny polityka zewnętrzna WE koncentrowała się przede wszystkim na pomocy rozwojowej. Ograniczenia wiązały się z istniejącym wówczas dwubiegunowym systemem międzynarodowym, który determinował wszystkie zachowania w polityce światowej. Nasilenie procesów dekolonizacyjnych w latach 60 . $\mathrm{XX}$ wieku i powstanie niezależnych państw w Afryce spowodowało potrzebę uregulowania na nowo stosunków $\mathrm{z}$ byłymi koloniami.

Wzajemne stosunki polityczne i gospodarcze między WE a wybranymi państwami Afryki Subsaharyjskiej oparte zostały na formule konwencji z Yaoundé, podpisanej 20 lipca 1963 roku, która weszła w życie 1 czerwca 1964 roku. Porozumienie zawarte zostało na pięć lat $\mathrm{z}$ możliwością renegocjacji w ostatnim roku przed upływem trwania umowy. Porozumienie zawarte zostało z 13 byłymi afrykańskimi koloniami francuskimi, Madagaskarem, 3 byłymi koloniami belgijskimi oraz Somalią, byłym terytorium zamorskim Włoch. Ogółem sygnatariuszami konwencji z Yaoundé zostało 18 państw: Burundi, Czad, Dahomej, Kamerun, Kongo, Gabon, Górna Wolta,

2 Przyjęcie w 2007 roku Wspólnej Strategii Afryki i UE (Joint Africa-EU Strategy - JAES) było odpowiedzią na potrzebę uczynienia polityki europejskiej bardziej spójną i przewidywalną. Uzgodniona na drugim szczycie UE-Afryka w Lizbonie strategia miała stać się spójnym dokumentem określającym kierunek rozwoju wzajemnych stosunków we wszystkich dziedzinach będących przedmiotem zainteresowania obu stron. Co zatem nowego pojawiło się w strategii, skoro od 2000 roku obowiązywała umowa z Cotonou - ramowy i kompleksowy dokument określający współpracę UE na rzecz rozwoju gospodarczego, społecznego i kulturowego państw AKP? Po pierwsze, strategia dotyczy całego kontynentu afrykańskiego, zarówno część śródziemnomorskiej, jak i Afryki Subsaharyjskiej. Po drugie, $\mathrm{w}$ dokumencie podkreśla się wzmocnienie i wyniesienie na wyższy poziom partnerstwa politycznego, tworząc partnerstwo równych sobie. Po trzecie, strony zobowiązały się do dalszego promowania pokoju i bezpieczeństwa, praworządności i praw człowieka, handlu i integracji regionalnej na kontynencie afrykańskim oraz innych ważnych kwestii związanych z rozwojem. Po czwarte, zapowiedziano znalezienie wspólnych odpowiedzi na globalne wyzwania i po piąte, promocję szeroko rozumianego partnerstwa dla wszystkich ludzi w Afryce i w Europie. D. Heidrich, Znaczenie wspólnej strategii Afryki i UE dla stosunków UE z Afryką, Komisja Europejska, Przedstawicielstwo w Polsce, http://ec.europa.eu/polska/ news/opinie/110127_ue_afryka_pl.htm\#10

3 M. Carbone, The EU in Africa: Increasing Coherence, Decreasing Partnership, w: The Foreign Policy of the European Union. Assessing Europe's Role in the World, red. F. Bindi, Brookings Institution Press, Washington 2010, s. 240. 
Madagaskar, Mali, Mauretania, Niger, Republika Środkowej Afryki, Rwanda, Senegal, Somalia, Togo, Wybrzeże Kości Słoniowej i Zair. Państwa te utworzyły grupę pod nazwą Stowarzyszone Państwa Afrykańskie i Malgaskie (inna nazwa używana w literaturze to Związek Państw Afrykańskich i Madagaskaru). ${ }^{4}$

Jak zauważają P. Frankowski i I. Słomczyńska, nawiązanie przez WE współpracy ze stowarzyszeniem państw afrykańskich podniosło ich status na arenie międzynarodowej, nadało specjalny status podobny do innych ugrupowań, a także uwiarygodniło ich działania w polityce zewnętrznej. ${ }^{5}$ Konwencję z Yaoundé wyróżniał jej nowatorski charakter. Była to jedna z pierwszy umów dotycząca współpracy między państwami Północy i Południa. Zakładała przede wszystkim wspólne konsultacje w dziedzinie gospodarczej, w tym promowanie wymiany handlowej przez eliminację ograniczeń taryfowych i ilościowych między stronami, a także stosowanie klauzul ochronnych. Te ostatnie mogły być używane na wniosek strony konwencji w przypadku zakłóceń w wymianie lub stwierdzonej szkodliwości dla rozwoju gospodarczego. Konwencja z Yaoundé była jednak w głównej mierze systemem, w ramach którego przekazywano środki pomocowe na rozwój państw afrykańskich. Czyniono to $\mathrm{w}$ ramach Europejskiego Funduszu Rozwoju (European Development Fund - EDF), a także przez narodowe kanały państw członkowskich zainteresowane rozwojem wzajemnej współpracy. Inwestycje, na które przekazywano środki, obejmowały: pomoc społeczną, infrastrukturę, współpracę technologiczną, dywersyfikację produkcji, stabilizację zysków z eksportu. Kategorie wydatków zostały w bardzo szczegółowy sposób wyznaczone przez państwa europejskie tak, że kraje afrykańskie nie miały praktycznie wpływu na rozdysponowanie środków ${ }^{6}$.

W 1969 roku podpisano II konwencję z Yaoundé, która niewiele różniła się od pierwszej. Na uwagę zasługuje przede wszystkim zwiększenie pomocy finansowej i materialnej w ramach EDF, a także utrwalenie obecności państw afrykańskich w systemie gospodarki światowej. Generalnie rezultaty obowiązywania konwencji z Yaoundé są niezadowalające. W literaturze przedmiotu wskazuje się przede wszystkim na brak wymiaru politycznego we wzajemnych stosunkach, a także „podtrzymywanie zależności kolonialnych i utrwalanie nierównego partnerstwa, co zapewniało ekonomiczną dominację Europy"?

\footnotetext{
4 K. Redłowska, USA i UE w Afryce Subsaharyjskiej. Współpraca i rywalizacja, Wydawnictwo Adam Marszałek, Toruń 2011, s. 145; P. Frankowski, I. Słomczyńska, op.cit., s. 48-49.

5 Ibidem, s. 49.

6 Ibidem, s. 50.

7 C. Cosgrove-Twitchett, Europe and Africa: from association to partnership, Sahxon House, Westmead 1978, s. 119, cytat za: P. Frankowski, I. Słomczyńska, op.cit., s. 50; M. Holland, The European Union and the Third World, Palgrave, London 2002, s. 32.
} 
Tabela 1. Współpraca WE z państwami afrykańskimi w latach 1957-1975

\begin{tabular}{|l|}
\hline \multicolumn{1}{|c|}{ Współpraca przed powołaniem konwencji z Lome } \\
\hline Traktat rzymski (1957) \\
Francja doprowadziła do stowarzyszenia swoich byłych kolonii z Europejską Wspólnotą Gospodarczą (EWG). \\
W ramach EWG wprowadzono system preferencji handlowych i zobowiązano się do wspierania wysitków \\
na rzecz rozwoju. \\
Powołano Europejski Fundusz Rozwoju (European Development Fund - EDF). \\
\hline Konwencje z Yaounde (1963-1975) \\
Uznano niepodlegtość państw afrykańskich. \\
Ustanowiono nowe ramy instytucjonalne w oparciu o Yaoundé I (1963-1969) i Yaoundé Il (1969-1975). \\
\hline Georgetown Agreement (1975) \\
Powołano do życia grupę pod nazwą kraje Afryki, Karaibów i Pacyfiku (AKP), której celem była koordynacja polityki \\
wobec EWG. \\
\hline
\end{tabular}

Źródło: Opracowanie własne na podstawie informacji uzyskanych z: Friedrich Ebert Stiftung: Cotonou Agreement ACP-EU, http://www.fes.de/cotonou/acp

Dochowując zasad wolnego handlu, w sposób dyskryminujący traktowano towary z krajów afrykańskich, które mogły być konkurencyjne dla produktów europejskich. Przede wszystkim podkreślano pogłębienie zależności gospodarczej i wymiany handlowej z WE, zwłaszcza przez korzystanie z systemu preferencji handlowych. Jednakże nie we wszystkich obszarach państwa afrykańskie mogły to robić. Na przykład preferencje taryfowe dla towarów, które stanowiły główną część eksportu państw afrykańskich, nie zostały wprowadzone (np. miedź, rudy żelaza), ponieważ nie były one pierwotnie objęte systemem ceł i dlatego WE nie mogła zapewnić im łatwiejszego dostępu do swojego rynku. ${ }^{8} \mathrm{~W}$ ostatniej fazie obowiązywania konwencji z Yaoundé okazało się, że skutki jej działania nie były tak korzystne, jak można było się spodziewać. Eksport z krajów należących do Stowarzyszenia na rynek WE wzrósł w latach 1958-1974 o 264\%, a państw afrykańskich pozostających poza Stowarzyszeniem o 930\%. Z kolei import z WE do państw stowarzyszenia o 205\%, a do krajów niestowarzyszonych o 285\%. ${ }^{9}$ Wyraźnie więc widać, że rozwój relacji handlowych WE z krajami afrykańskimi spoza stowarzyszenia był o wiele szybszy niż w przypadku specjalnych preferencji dla krajów objętych konwencją z Yaoundé.

Mimo fali krytyki pod adresem WE pozytywnym efektem działania konwencji było przede wszystkim włączenie państw z Afryki do systemu handlu międzynarodowego i stworzenie podstaw integracji regionalnej. Ze względu na ogromne dysproporcje gospodarcze, społeczne i polityczne trudno sobie wyobrazić inny sposób nawiązania relacji niż opierający się asymetrycznej liberalizacji i systemie pomocy

${ }^{8}$ M. Holland, ibidem, s. 29.

9 C. Cosgrove-Twitchett, op.cit., s. 125, cytat za: P. Frankowski, I. Słomczyńska, op.cit., s. 53. 
rozwojowej. Ponadto głównym sukcesem była pomoc rozwojowa oferowana afrykańskim państwom LDCs, która w oparciu o ustalenia konwencji Yaoundé II szacowana była na 1 mld dol. ${ }^{10}$

\section{System konwencji z Lomé: w stronę partnerstwa WE-AKP}

W zmieniających się uwarunkowaniach międzynarodowych, do których należało przystąpienie do WE Wielkiej Brytanii (1973), a także coraz większa świadomość państw afrykańskich w dążeniu do realizacji interesów na arenie międzynarodowej, pojawiła się potrzeba ustanowienia nowych relacji. Negocjacje nad kształtem porozumienia mającego zastąpić konwencje z Yaoundé trwały prawie dwa lata i zakończyły się przyjęciem konwencji z Lomé 28 lutego 1975 roku (weszła w życie 1 kwietnia 1976 roku). Stronami konwencji było 9 państw EWG oraz 46 państw z Afryki, Karaibów i Pacyfiku (AKP). W sumie przyjętych zostało pięć konwencji, negocjowanych co pięć lat od 1975 do 2000 roku. Zakładano, że umowy miały być bardziej kompleksowe $\mathrm{i}$ innowacyjne. Po pierwsze, decyzje miały być podejmowanie $\mathrm{w}$ ramach negocjacji między wszystkimi stronami, a nie jednostronnie przez WE, jak miało to miejsce w konwencji z Yaoundé. Po drugie, utworzono wspólne instytucje, aby umożliwić stały dialog między partnerami. Po trzecie, państwa AKP uzyskały stałą pulę środków w okresie pięciu lat niezależnie od wyników. Po czwarte, handel oparty został na jednostronnej formule specjalnych preferencji przyznawanych na rzecz państw AKP, a dodatkowo większość towarów z państw stowarzyszonych cieszyło się bardzo niską, bądź zerową stawką celną na rynku WE. ${ }^{11}$

Najważniejszą zmianą w porównaniu z poprzednimi umowami była formuła partnerstwa. W konwencji z Lomé podkreślano partnerski charakter wzajemnych relacji, choć, jak zauważa M. Holland, koncepcja ta była użyta na wyrost i nie odzwierciedlała faktycznych związków między stronami, które charakteryzowały się głębokimi dysproporcjami. ${ }^{12}$ Twierdzenie to jest jak najbardziej słuszne, niemniej użycie niniejszej formuły było zabiegiem podyktowanym chęcią podniesienia statusu międzynarodowego państw AKP, uznania ich suwerenności oraz pokazania

10 Stopień wykorzystania pomocy nie jest jednak do końca znany. Wiele wskazuje, że mimo szczytnych założeń wiele środków zostało przywłaszczonych przez osoby prywatne znajdujące się w kręgach rządowych i administracyjnych państw afrykańskich. Ponadto pomoc trafiała do przedsiębiorstw francuskich, brytyjskich i niemieckich. Ibidem, s. 53.

11 M. Carbone, op.cit., s. 240.

12 M. Holland, op.cit., s. 35. 
wiarygodności i samodzielności w działaniu. Chociaż nikt nie miał wątpliwości co do rzeczywistego potencjału gospodarczego i politycznego państw afrykańskich, to formuła ustanowienia nowych ram instytucjonalnych dawała im większą pewność i zachętę do działania na arenie międzynarodowej.

Faktycznie WE sprawowała kontrolę nad urzeczywistnianiem celów i zadań przyjętych w konwencji, szczególnie dotyczących środków pomocowych. Chociaż istniało pozorne przyzwolenie na samodzielne decydowanie o alokacji przyznanych środków finansowych, to do wyłącznej kompetencji Europejskiego Funduszu Rozwojowego należała ocena finansowanych projektów. Umożliwiało to zablokowanie projektów proponowanych przez państwa AKP nieodpowiadających wymogom stawianym przez WE. Ponadto podział funduszy między poszczególne państwa AKP odbywał się na podstawie wytycznych ustalanych jednostronnie przez WE. Priorytet miały więc te państwa, które realizowały politykę bliższą interesom Wspólnoty. ${ }^{13}$

Nowa formuła rozwoju wzajemnych stosunków zawarta w konwencji z Lomé nie była jednak tak satysfakcjonująca, jak mogło się wydawać na początku. Główne zastrzeżenie wiązało się z brakiem wyraźnej poprawy warunków społecznych i gospodarczych w państwach afrykańskich. Kraje te w przeważającej mierze nie zdołały osiągnąć zadowalających wskaźników gospodarczych. Powszechnie panująca opinia na temat skutków dwóch pierwszych konwencji z Lomé jest zdecydowanie negatywna. ${ }^{14}$ Przede wszystkim chodziło o niespełnione oczekiwania ze strony państw AKP. Najbardziej widocznym tego przejawem była dalsza pauperyzacja tamtejszych społeczeństw i znikomy udział towarów w rynku wspólnotowym. Mimo stopniowo zwiększanych środków pomocowych WE efekty społeczne w państwach AKP były mocno niezadowalające. Dlatego pod wpływem doświadczeń Wspólnota zdecydowała się na poważne zmiany w ramach III konwencji z Lomé, szczególnie dotyczące polityki pomocowej. Należało zmienić dotychczasowe podejście w zakresie udzielania pomocy z poziomu centralnego, gdzie środki były w dyspozycji rządu danego kraju, na rzecz konkretnych projektów i grup potrzebujących.

Nieefektywne wykorzystanie pomocy rozwojowej i w konsekwencji stopniowe zubożenie społeczeństw afrykańskich, mimo ogromnych nakładów ze strony WE, wynikało z kilku wzajemnie zależnych czynników. Po pierwsze, ze względu na słabe struktury państwowe i administracyjne nie było możliwości alokacji środków z WE i w przeważającej mierze były one źle wykorzystywanie, bądź zawłaszczane przez centralne lub lokalne struktury władzy. Sytuację pogarszała wszechobecna korupcja.

13 P. Frankowski, I. Słomczyńska, op.cit., s. 58-59.

14 A. Banthia, Success of Failure? An Evaluation of Fifty Years (1957-2007) of European Union Development Policy in Africa, Caribbean and the Pacific, „Political Perspective”, EPRU, 2007, Issue 2 (1), s. 1-36; M. Carbone, op.cit., s. 241. 
Po drugie, niski stopień inwestycji w najbardziej potrzebne sektory gospodarki. Po trzecie, brak wykwalifikowanej grupy ekspertów i potencjału społecznego w państwach najuboższych. Po czwarte, tradycyjne utrwalane schematy relacji handlowych opartych na strukturach kolonialnych.

Próbą zmiany dotychczasowych praktyk obowiązujących w ramach dwóch pierwszych konwencji z Lomé było wprowadzenie do III konwencji zapisów dotyczących demokracji i ochrony praw człowieka. Ze względu na silny opór państw AKP zabieg ten nie udał się. Negocjacje nad kształtem III konwencji trwały rok i zakończyły się w grudniu 1984 roku. Wspólnocie udało się zwiększyć kontrolę nad programem wydawania środków na pomoc rozwojową, a także określić priorytetowe obszary dla przyszłych inwestycji. Zaliczono do nich rozwój obszarów wiejskich, rybołówstwo, ochronę środowiska naturalnego. ${ }^{15}$ Jednak ze względu na duże zróżnicowanie interesów i trudności z wypracowaniem wspólnego stanowiska kraje AKP nie potrafiły przeforsować swoich celów i wprowadzić do umowy własnych założeń. Ich niezadowolenie było tym większe, że pogarszająca się sytuacja gospodarcza nie skłoniła UE do zwiększenia puli środków pomocowych. ${ }^{16}$

Pod koniec 1988 roku rozpoczęły się rozmowy w sprawie kolejnej, IV konwencji z Lomé. Nowym elementem były ustalenia dotyczące podziału funduszy pomocowych. Chodziło o to, aby środki trafiały na finansowanie najbardziej potrzebnych projektów „nie jako bezpośrednia pomoc, ale jako wsparcie dla rozwiązań strukturalnych" ${ }^{17}$ Było to m.in. podyktowane koniecznością dostosowania się do programów pomocowych realizowanych przez Bank Światowy i Międzynarodowy Fundusz Walutowy. Ponadto Wspólnocie udało się włączyć do IV konwencji kwestię praw człowieka i zasadę „dobrych rządów”. Nastąpiło powolne rozszerzanie współpracy o nowe dziedziny, nie tylko związane ze stosunkami handlowymi. Wspólnota skierowała uwagę państw afrykańskich na kwestię należącą do kanonu podstawowych wartości, którymi kierowały się państwa europejskie. Po raz pierwszy we wspólnej umowie poruszono zagadnienia polityczne, które wyznaczyły odtąd kierunek działania WE w relacjach z państwami afrykańskimi.

Ostatnia, V konwencja z Lomé została przyjęta w listopadzie 1995 roku. Nowe dziedziny, które zdołano poruszyć w poprzedniej umowie, zostały jeszcze bardziej uwypuklone. Odtąd problematyka praw człowieka, rządów prawa i pokojowego rozwiązywania sporów jest stałym elementem dwustronnych umów. Pojawiła się także idea tworzenia stałego dialogu politycznego, co miało zaowocować wprowadzeniem

15 P. Frankowski, I. Słomczyńska, op.cit., s. 64.

16 E.R. Grilli, The European Community and the developing countries, Cambridge University Press, Cambridge 1993, s. 37-39.

17 P. Frankowski, I. Słomczyńska, op.cit., s. 67. 
spotkań z mniejszą liczbą państw, według klucza regionalnego. Zabiegu tego dokonano dopiero $\mathrm{w}$ czasie negocjacji nad przyjęciem porozumień o partnerstwie gospodarczym (EPA) na początku XXI wieku, co i tak napotykało liczne głosy sprzeciwu. W dziedzinie stosunków handlowych UE zapowiedziała podjęcie stosownych instrumentów w celu wzmocnienia konkurencyjności towarów eksportowych na rynku unijnym. Zobowiązano się do wzmocnienia eksportu państw AKP, ale także handlu wewnętrznego.

\section{Porozumienia z Cotonou: normalizacja stosunków}

Ze względu na zmieniającą się sytuację międzynarodową i znikome efekty wynikające z obowiązywania konwencji z Lomé postanowiono zmienić dotychczasowy jej kształt i wprowadzić nowe elementy. ${ }^{18}$ Pogarszający się poziomu życia społeczeństw afrykańskich (wzrosła liczba państw zaliczonych do najmniej rozwiniętych - LDCs) i utrwalające się więzi afrykańsko-wspólnotowe oparte na pomocy materialnej, finansowej i specjalnych preferencjach handlowych skłoniły UE do zmiany podejścia. ${ }^{19}$ Przede wszystkim rozczarowujące było to, że mimo wielu wysiłków podejmowanych w oparciu o konwencje z Lomé nie zdołano zwiększyć udziału państw afrykańskich w wymianie handlowej UE. Wręcz przeciwnie, między 1975 a 1990 rokiem udział ten spadł o $3 \% .{ }^{20}$ Główny cel UE, jakim była wymiana handlowa, nie przyniósł spodziewanych efektów. Wśród badaczy przeważają wątpliwości, czy preferencje handlowe działały na korzyść państw najuboższych i czy nie utrwaliły złych nawyków w wymianie handlowej, w konsekwencji przyczyniając się do pogorszenia ich bilansu handlowego. ${ }^{21}$ Biorąc po uwagę doświadczenia z poprzednich konwencji, nowe porozumienie różniło się zasadniczo w swoich założeniach, osadzone było w nowych uwarunkowaniach międzynarodowych i brało pod uwagę realne zagrożenia wynikające z niestabilności, ubóstwa i słabego potencjału społeczno-gospodarczego.

Zmiana polityki UE wobec Afryki, czego wyrazem było porozumienie z Cotonou, a nie kolejna umowa $\mathrm{z}$ serii konwencji z Lomé, oznaczała zerwanie z dotychczasowym

\footnotetext{
18 Green Paper, European Commission 1996, s. viii.

19 W. Brown, The European Union and Africa. The Restructuring of North-South Relations, I.B. Tauris Publ., London 2002, s. 133.

${ }_{20}$ G. Olivier, The Cotonou Agreement and South Africa, w: 50 years of the EU in the World. The European Union as a Global Actor, red. T. Kołodziej, Oficyna Wydawnicza WSM, Warszawa 2008, s. 10.

${ }^{21}$ M. Holland, op.cit., s. 40.
} 
postrzeganiem Afryki i budowę nowych ram współpracy. Było to rezultatem występowania kilku przynajmniej czynników:

- zmieniającej się roli UE jako aktora globalnego;

- potrzeby poszukiwania nowych źródeł energii (dywersyfikacja dostawców i źródeł);

- zwiększonego zainteresowania Afryką innych państw, takich jak Chiny czy USA, które dążyły do nawiązania współpracy gospodarczej;

- większej aktywności organizacji międzynarodowych: MFW, BŚ, WTO, OECD.

$\mathrm{W}$ oparciu o konwencję z Lomé strategia Unii koncentrowała się na rozwoju przez handel i inicjatywach pomocy rozwojowej. $Z$ kolei w porozumieniu z Cotonou cele te zostały zawężone do redukcji ubóstwa, zrównoważonego rozwoju i integracji z gospodarką światową. W związku z tym do podstawowych celów zaliczono:

- rozwój dialogu politycznego;

- partnerstwo gospodarcze i zaangażowanie zarówno aktorów państwowych, jak i pozapaństwowych;

- zastąpienie systemu jednostronnych preferencji handlowych umowami o partnerstwie gospodarczym (Economic Partnership Agreements - EPA);

- pomoc finansową i techniczną;

- integrację regionalną. ${ }^{22}$

$\mathrm{W}$ porozumieniu z Cotonou starano się znaleźć równowagę między pomocą a handlem $z$ jednej strony, $\mathrm{z}$ drugiej zaś między demokracją, ochroną praw człowieka i dobrymi rządami, a więc zasadami związanymi z systemem pomocy rozwojowej i redukcją ubóstwa. Wprowadzono regułę warunkowości, co oznaczało, że otrzymujący pomoc powinni respektować określone zasady i wartości, którymi kieruje się UE (np. zasada „dobrych rządów” czy ochrona praw człowieka). ${ }^{23}$ Wprawdzie restrykcyjność formuły warunkowości została nieco poluzowana ze względu na sprzeciw krajów AKP, nie oznaczało to jednak, że została wyeliminowana. Znacznie trudniej można było ją egzekwować po spełnieniu określonych warunków. ${ }^{24}$

Umowa z Cotonou zawarta została na dwadzieścia lat. Zakres i obszary działania dotyczyły właściwie każdej sfery aktywności międzynarodowej. Jest to cały katalog

22 Cotonou Infokit: The Cotonou Agreement at a Glance (2). Maastricht: ECDPM, http://www.ecdpm. org/Web_ECDPM/Web/...

23 G. Olivier, op.cit., s. 11.

24 Zasada warunkowości nie zawsze jest stosowana, ponieważ, jak się okazało, Komisja waha się co do nakładania sankcji na kraje rozwijające się, które nie dotrzymują podjętych zobowiązań w zakresie poszanowania praw człowieka, dobrego rządzenia i demokratyzacji, dlatego Parlament Europejski wezwał Komisję, aby brała pod uwagę nakładanie sankcji w każdym przypadku w razie potrzeby, ale jednocześnie starannego zbadania skutków takich sankcji dla ludności krajów-beneficjentów. Parlament Europejski, http://eur-lex.europa.eu/LexUriServ/LexUriServ.do?uri=OJ:C:2012:296E:0001:0013:PL:PDF 
spraw, przed którymi stoi współcześnie każde państwo czy grupa integracyjna. W przeciwieństwie do umów (konwencji z Yaoundé czy Lomé), które koncentrowały się na wymianie handlowej i pomocy rozwojowej, porozumienie z Cotonou było odwróceniem poprzedniego trendu. Wiele miejsca poświęcono sprawom pokoju i bezpieczeństwa, zapobieganiu rozwoju konfliktów zbrojnych oraz kwestii zarządzania sytuacjami kryzysowymi. Przyjęcie nowego porozumienia w marcu 2000 roku (weszło w życie w kwietniu 2003 roku) oznaczało faktyczne uznanie państw AKP za pełnoprawnych uczestników polityki światowej, co podnosiło ich wiarygodność na arenie międzynarodowej i czyniło potencjalnymi partnerami względem stron trzecich.

Elementem, który pozostał prawie niezmieniony, była struktura wspólnych instytucji (część druga porozumienia z Cotonou) - Rady Ministrów, Komitetu Ambasadorów oraz Wspólnego Zgromadzenia Parlamentarnego. Porozumienie opierało się na urzeczywistnianiu dwóch zasadniczych celów, którym podporządkowane zostały określone zadania. Były to: wspieranie szeroko pojętego rozwoju krajów AKP, czemu miało służyć budowanie pokoju i bezpieczeństwa oraz stabilizacji politycznej i społecznej oraz urzeczywistnianie celów milenijnych, a także integracja z gospodarką światową - włączenie partnerów z Południa do głównego nurtu gospodarki światowej przez liberalizację handlu, reformy strukturalne oraz porozumienia regionalne. Porozumienie z Cotonou oparte zostało na trzech wzajemnie uzupełniających się filarach: politycznym, finansowym i ekonomicznym (por. tabela 2).

Tabela 2. Porozumienie z Cotonou 2000-2020

Filar polityczny
Dialog polityczny
Reguły i zasada warunkowości
Wsparcie dla ściśle określonych obszarów działania (np. polityka bezpieczeństwa)

\section{Filar finansowy}

Europejski Fundusz Rozwoju (EDF)

Ułatwienia w przyznawaniu grantów

Utatwienia inwestycyjne

Proces programowania pomocy

\section{Filar ekonomiczny}

Handel: porozumienia o współpracy gospodarczej (Economic Partnership Agreements - EPAs)

Źródło: Opracowanie własne na podstawie informacji uzyskanych z: Friedrich Ebert Stiftung, op.cit. 


\subsection{Cel pierwszy: bezpieczeństwo i stabilizacja polityczna}

Priorytetem we wzajemnych stosunkach jest rozwój krajów AKP, szczególnie tych najmniej rozwiniętych (LCDs). Podstawą rozwoju krajów afrykańskich jest sprzyjające otoczenie międzynarodowe i wewnętrzne. Dlatego w umowie z Cotonou nacisk położono na rozwój demokracji, ochrony praw człowieka, rządów prawa, „dobrych rządów", które to wartości, jak stwierdzono, przyczyniają się do pokoju i bezpieczeństwa międzynarodowego. ${ }^{25} \mathrm{Na}$ uwagę zasługuje zwłaszcza pojęcie „dobrych rządów”, które należy do podstawowych zasad we wzajemnej współpracy. Oznacza ono „jasne i odpowiedzialne zarządzanie zasobami ludzkimi, naturalnymi, gospodarczymi i finansowymi w celu osiągnięcia sprawiedliwego i zrównoważonego rozwoju. Wiąże się z otwartymi procedurami podejmowania decyzji, przejrzystymi i odpowiedzialnymi instytucjami, kierowaniem się zasadami prawa przy zarządzaniu i dystrybucji zasobów, a także przeciwdziałaniem i zwalczaniem korupcji”. ${ }^{26}$ Prawo do włączenia się do dialogu politycznego uzyskały nie tylko jednostki państwowe, rządowe i terytorialne, ale także organizacje pozarządowe i inne instytucje obywatelskie.

Rozwój państw afrykańskich możliwy jest wyłącznie w warunkach pokoju i bezpieczeństwa. Dlatego UE położyła nacisk na zapobieganie konfliktom i zarządzanie sytuacjami kryzysowymi. Przedmiotem intensywnej współpracy stały się kwestie związane ze zwalczaniem terroryzmu, przestępczości zorganizowanej, proliferacji broni masowego rażenia (art. 11 umowy z Cotonou). Ważnym, ale jednocześnie kontrowersyjnym tematem stały się kwestie migracji i readmisji. Dotyczyło to uznania przez każdą ze stron umowy - zarówno UE, jak i krajów AKP, powrotu i readmisji wszystkich swoich obywateli przebywających nielegalnie na terytorium drugiej strony, na wniosek państwa członkowskiego UE lub każdego państwa AKP i dokonania tego bez dodatkowych formalności (art. 23, p. 5ci). Oznaczało to przejęcie przez kraje AKP odpowiedzialności za migracje swoich obywateli, a także ponoszenie kosztów związanych z ich powrotem. Ważnym elementem było włączenie działań przeciwdziałających ruchom migracyjnym. Były to przede wszystkim: redukcja ubóstwa, zwiększenie zatrudnienia, rozwój sektora prywatnego, budowa społeczeństwa obywatelskiego.

Tradycyjnie głównym obszarem współpracy jest rozwój gospodarczy państw AKP. Strony zobowiązały się do wspierania w państwach AKP sektora prywatnego, zwiększania inwestycji, reform makroekonomicznych i strukturalnych. Położono nacisk nie tylko na promowanie eksportu z państw AKP, ale przede wszystkim

25 The Cotonou Agreement, Cotonou, June 23, 2000, art. 9, s. 22, http://ec.europa.eu/europeaid/where/ acp/overview/documents/devco-cotonou-consol-europe-aid-2012_en.pdf

26 Ibidem, art. 9, p. 3. 
postanowiono silniej wesprzeć rynki wewnętrzne, mobilizując krajowe zasoby siły roboczej, rozwijać poszczególne sektory produkcji, szczególnie rolnictwa i przetwórstwa, a także turystykę (art. 21-25).

Strony porozumienia zapowiedziały ponadto podjęcie współpracy w następujących obszarach: równouprawnienie, przeciwdziałanie i walka $z$ epidemiami i chorobami zakaźnymi oraz HIV/AIDS, ochrona środowiska i zasobów naturalnych, zmiany klimatyczne, rozwój instytucji i budowa potencjału ludzkiego (art. 31-33). Nowością porozumienia jest włączenie do dialogu politycznego przedstawicieli społeczeństwa obywatelskiego oraz sektora prywatnego.

Ważną częścią relacji UE-AKP jest współpraca regionalna i integracja. Jest to niezbędny warunek do stworzenia bezpieczeństwa i pokoju oraz punkt wyjścia do rozwoju gospodarczego, zgodnie z założeniami przyjętymi w art. 28 porozumienia z Cotonou. Dlatego postanowiono wspierać integrację rynków państw AKP, co miałoby prowadzić do swobodnego przepływu osób, towarów, usług i kapitału, pracy oraz technologii między państwami członkowskimi. Współpraca regionalna powinna opierać się, zgodnie z założeniem, na koordynacji i harmonizacji polityk państw AKP, co pozostaje również wyzwaniem dla samej UE. Współpraca regionalna jest podstawą realizacji koncepcji zrównoważonego rozwoju. Jest obecna we wszelkich działaniach, które proponuje się w porozumieniu z Cotonou, a także kluczem dla nawiązywania umów gospodarczych z UE (EPA). ${ }^{27}$

\subsection{Cel drugi: integracja z gospodarką światową}

Integracja państw AKP z gospodarką światową to podstawowy cel współpracy między państwami Północy i Południa. Zwiększenie udziału w handlu światowym, aktywniejszy udział w negocjacjach wielostronnych, zmniejszenie zależności od eksportu jednego lub kilku towarów, dywersyfikacja gospodarek państw AKP to tylko niektóre cele wymienione $\mathrm{w}$ art. 34 porozumienia $\mathrm{z}$ Cotonou. Podstawowym instrumentem służącym urzeczywistnianiu tych celów są umowy EPA. Mają one nie tylko pomóc krajom AKP we włączeniu się do głównego nurtu gospodarki światowej, ale także przyczynić się do szybszej integracji regionalnej i poprawy dynamiki handlu między państwami Południa (art. 36). Uzgodniono, że postanowienia dotyczące porozumień EPA mają być wprowadzane stopniowo, a negocjacje odbywać się tylko z krajami AKP do tego przygotowanymi, zgodnie z procedurami wyznaczonymi przez nie same.

27 Umowa z Cotonou, art. 34. 
Bezpośrednią przesłanką za przyjęciem nowego typu porozumień gospodarczych między UE a państwami AKP było dostosowanie się do regulacji handlowych WTO. System specjalnych preferencji wobec ograniczonej liczby członków WTO, a więc grupy AKP, naruszał podstawową zasadę niedyskryminacji. Członków tej organizacji obowiązuje bowiem każdorazowe „zwolnienie” w przypadku stosowania preferencji wobec wybranych państw lub grup, które ze swej natury są dyskryminujące wobec pozostałych członków. Warunkiem utrzymania takich preferencji jest wystąpienie o zgodę na tymczasowe „zwolnienie” ze stosowania regulacji WTO lub ustanowienie strefy wolnego handlu opartej na wzajemnych preferencjach każdej ze stron umowy. Takiego warunku nie spełniały umowy między UE i państwami AKP (porozumienia z Lomé), które opierały się na jednostronnych preferencjach Wspólnoty i tym samym stały w sprzeczności z regułami WTO. Po okresie tymczasowego „zwolnienia” UE zapowiedziała przyjęcie porozumień mających na celu stworzenie stref wolnego handlu z krajami AKP, a więc negocjowanie nowych umów gospodarczych zgodnych $\mathrm{z}$ art. XXIV GATT, gdzie wymaga się, aby liberalizacja dotyczyła „zasadniczo całości wymiany handlowej" między wszystkimi uczestnikami porozumienia. Zobowiązania UE wymagały podjęcia stosownych negocjacji z krajami afrykańskimi w celu utworzenia zapowiedzianych umów o partnerstwie gospodarczym. Zgodnie z decyzją Rady z 17 lipca 2002 roku wszystkie negocjacje związane z tworzeniem porozumienia EPA miały obejmować całą wymianę handlową (co najmniej $80 \%$ wymiany towarowej) oraz handel usługami, a także inwestycje oraz dziedziny związane $z$ handlem.

\section{Tabela 3. Przegląd umów EPA z państwa i ugrupowaniami regionalnymi w Afryce} (stan na 12.07.2012)

\begin{tabular}{|c|c|c|}
\hline $\begin{array}{l}\text { Region/Ugrupowanie } \\
\text { regionalne }\end{array}$ & Obecny status & Planowane działania \\
\hline Afryka Zachodnia & $\begin{array}{l}\text { Tymczasową umowę EPA (Interim Economic } \\
\text { Partnership Agreement) miały podpisać } \\
\text { Ghana i Wybrzeże Kości Stoniowej. } \\
\text { Żadna z umów nie została ratyfikowana, } \\
\text { a ostatecznie podpisało ją tylko Wybrzeże } \\
\text { Kości Stoniowej w listopadzie } 2008 \text { roku. }\end{array}$ & $\begin{array}{l}\text { Kontynuowane są negocjacje } \\
\text { na temat dostępu do rynku } \\
\text { oraz współpracy na rzecz rozwoju. }\end{array}$ \\
\hline Afryka Centralna & $\begin{array}{l}\text { W styczniu } 2009 \text { roku Kamerun podpisał } \\
\text { tymczasowe porozumienie EPA. } \\
\text { Umowa nie została jeszcze ratyfikowana. }\end{array}$ & $\begin{array}{l}\text { Negocjacje na temat dostępu } \\
\text { do rynku, reguł pochodzenia towarów, } \\
\text { usług, inwestycji, dziedzin zwiazzanych } \\
\text { z handlem, współpracy rozwojowej. }\end{array}$ \\
\hline $\begin{array}{l}\text { Afryka Wschodnia } \\
\text { i Południowa (Eastern } \\
\text { and Southern Africa - ESA) }\end{array}$ & $\begin{array}{l}\text { Mauritius, Seszele, Zimbabwe i Madagaskar } \\
\text { podpisały tymczasową umowę EPA w } 2009 \\
\text { roku. Umowy są tymczasowo realizowane } \\
\text { od maja } 2012 \text { roku. }\end{array}$ & $\begin{array}{l}\text { Negocjacje w następujących } \\
\text { obszarach: handel towarami, usługami, } \\
\text { dziedziny związane z handlem, pomoc } \\
\text { rozwojowa. Szczegółowe negocjacje } \\
\text { na temat podatków eksportowych, } \\
\text { reguł pochodzenia, klauzul ochronnych } \\
\text { w rolnictwie. }\end{array}$ \\
\hline
\end{tabular}




\begin{tabular}{|c|c|c|}
\hline $\begin{array}{l}\text { Wspólnota Afryki } \\
\text { Wschodniej (Eastern } \\
\text { African Community } \\
\text { - EAC) }\end{array}$ & $\begin{array}{l}\text { Burundi, Rwanda, Tanzania, Kenia i Uganda } \\
\text { przystąpiły do umowy ramowej EPA } \\
\text { w listopadzie } 2007 \text { roku. Jednakże } \\
\text { nie zostały one jeszcze podpisane, } \\
\text { ani ratyfikowane. Obecnie negocjują umowę } \\
\text { regionalną EPA. }\end{array}$ & $\begin{array}{l}\text { Negocjowana jest umowa regionalna } \\
\text { w następujących dziedzinach: } \\
\text { pomoc rozwojowa, rolnictwo, reguły } \\
\text { pochodzenia. }\end{array}$ \\
\hline $\begin{array}{l}\text { Południowoafrykańska } \\
\text { Wspólnota Rozwoju (South } \\
\text { African } \\
\text { Development } \\
\text { Community - SADC) }\end{array}$ & $\begin{array}{l}\text { Botswana, Lesotho, Suazi i Mozambik } \\
\text { podpisały umowę w czerwcu } 2009 \text { roku, } \\
\text { a Namibia ostatecznie ogłosiła brak } \\
\text { gotowości do przyjęcia umowy. }\end{array}$ & $\begin{array}{l}\text { Państwa, które podpisały umowe } \\
\text { o charakterze przejściowym EPA, } \\
\text { nie zdecydowały się na jej czasowe } \\
\text { wprowadzenie w życie. Rozmowy } \\
\text { toczą się w sprawie dostępu } \\
\text { do rynku. Głównym podmiotem } \\
\text { zaangażowanym w rokowania } \\
\text { ze strony SADC jest RPA. } \\
\text { Z RPA prowadzone są negocjacje } \\
\text { na temat dostępu do rynku, handlu } \\
\text { tekstyliami, reguł pochodzenia i } \\
\text { dziedzin związanych z handlem. }\end{array}$ \\
\hline
\end{tabular}

Źródło: Overview of EPA, EU Trade, European Commission, July 12, 2012, http://trade.ec.europa.eu/doclib/ docs/2009/september/tradoc_144912.pdf

Podstawą podejścia UE do państw afrykańskich, opartego na podziale regionalnym, było przekonanie, że integracja regionalna między państwami Afryki przyczyni się do poprawy ich wymiany handlowej w wymiarze ilościowym i jakościowym. Tym samym umożliwi im efektywne występowanie jako zwarta grupa w negocjacjach z UE. Unii zależało przede wszystkim na przyjęciu porozumień handlowych, zmierzających do liberalizacji wzajemnego handlu, zniesieniu barier taryfowych oraz stopniowej standaryzacji eksportowanych produktów, zgodnych z wymogami sanitarnymi UE i WTO. Z kolei państwa afrykańskie podkreślały wymiar rozwojowy i naciskały na szersze włączenie kwestii pomocy rozwojowej do proponowanych umów.

Rokowania z krajami afrykańskimi rozpoczęły się we wrześniu 2002 roku i miały zakończyć się przyjęciem ostatecznych porozumień o partnerstwie gospodarczym (EPA) w styczniu 2008 roku. Ze względu na presję czasową i szereg trudnych tematów nie udało się doprowadzić do przyjęcia ostatecznych porozumień EPA. W konsekwencji różne kraje przyjęły różne rozwiązania oparte na propozycji EPA, ale dostosowane do własnych uwarunkowań. Niektóre z nich zgodziły się na podpisanie umów, ale o charakterze przejściowych. Należały do nich Ghana, Wybrzeże Kości Słoniowej, Kamerun. Inne zdecydowały się na prowadzenie wymiany handlowej na warunkach przewidzianych w EPA (Kongo, Gabon) lub wybrały opcję zachowania specjalnych preferencji w ramach systemu ogólnego (GSP). Jeszcze inne kraje należące do grupy państw LDCs - postanowiły prowadzić swoją wymianę handlowa z UE, opierając się na programie zatytułowanym „Wszystko oprócz broni” („Everything but arms" - EBA). Na jego podstawie UE przyznaje produktom importowanym 
z krajów LDCs bezcłowy dostęp do swojego rynku, z wyjątkiem broni i amunicji. ${ }^{28}$ Pozostała grupa państw afrykańskich postanowiła prowadzić wymianę handlową w oparciu o EPA, mimo braku formalnych uzgodnień wiążącej umowy. Te, które zdecydowały się podpisać umowę przejściową EPA, uczyniły to pod presją spowodowaną wygaśnięciem preferencyjnego systemu w ramach umowy z Cotonou.

Ze względu na fakt, że większość krajów afrykańskich zaliczanych jest do grupy najmniej rozwiniętych (LDCs), a umów EPA nie udało się jak na razie wprowadzić, program „Wszystko oprócz broni” pozostaje głównym porozumieniem regulującym kontakty handlowe $z$ UE. Jego stosowanie jest jednak obarczone ryzykiem, ponieważ nie wiadomo, jak długo będzie obowiązywać. Brak uzgodnień dotyczących porozumień o partnerstwie gospodarczym EPA i wygaśnięcie EBA może okazać się dla państw afrykańskich wysoce niekorzystne. Mogą one być przez pewien czas, do momentu zawarcia nowej umowy, pozbawione preferencyjnego dostępu na rynek UE.

\subsection{Przebieg rokowań}

Nowym podejściem w ramach negocjacji umów EPA, w porównaniu z konwencją Yaoundé i Lomé, był podział krajów AKP na sześć odrębnych regionów. W przypadku Afryki był to region Afryki Zachodniej, Afryki Środkowej, Afryki Wschodniej i Południowej, Afryki Południowej oraz RPA. W tym ostatnim przypadku chodziło o wyróżnienie pozycji tego państwa na tle pozostałych krajów regionu i włączenie go do współpracy z UE na warunkach odpowiadających jego poziomowi rozwoju i pozycji w regionie (por. tabela 3 ).

Kraje Afryki Zachodniej prowadziły negocjacje z ramienia ugrupowania ECOWAS (Economic Community of West African States). Pierwsza faza rokowań dotyczyła porozumień handlowych i pomocy rozwojowej, druga - kwestii uzupełniających, w tym m.in. ochrony środowiska. ${ }^{29}$ Do tej pory przyjęto dwie tymczasowe umowy (Interim EPA) z Ghaną i Wybrzeżem Kości Słoniowej, które stały się wzorcowymi porozumieniami dla pozostałych państw. Przewidziano w nich stopniową liberalizację handlu w taki sposób, aby znoszenie barier nie prowadziło do poważnych zakłóceń na rynku państw afrykańskich, przy jednoczesnym rozszerzeniu dostępu na rynek UE. Harmonogram stopniowej liberalizacji kończył się w przypadku tych państw w 2022 roku. Ponadto, ze względu na wysoką wrażliwość gospodarek państw

28 Generalized System of Preferences: Everything But Arms Initiative, http://ec.europa.eu/trade/issues/ global/gsp/eba/index_en.htm

29 Ibidem, s. 136-140. 
AKP na wahania i koniunkturę na rynkach światowych, ważne było wprowadzenie mechanizmów ochronnych, pozwalających na czasową ochronę rynku państw AKP.

Kraje Afryki Środkowej reprezentowane były przez ugrupowanie CEMAC (Economic Community of Central African States) oraz wyspy św. Tomasz i Książęca. Umowę przejściową EPA podpisano jedynie z Kamerunem, a Kongo i Gabon rozpoczęły prowadzenie wymiany handlowej na podstawie systemu ogólnych preferencji (GSP).

Z kolei państwa z Afryki Wschodniej i Południowej występowały w negocjacjach z UE z ramienia ugrupowania pod nazwą Wschodnioafrykańska Wspólnota (East African Community - EAC) oraz Afryka Wschodnia i Południowa (East and Southern Africa - ESA). Była to najliczniejsza grupa spośród wszystkich członków ugrupowań afrykańskich. Umowy przejściowe zawierające harmonogram wzajemnej liberalizacji z UE podpisały Seszele, Zimbabwe, Mauritius i Madagaskar.

Istniała także możliwość podpisania tzw. umowy ramowej EPA (Framework EPA), co w listopadzie 2008 roku uczynili członkowie tworzący ugrupowanie EAC (East African Community), tj. Kenia, Uganda, Tanzania, Rwanda, Burundi. Umowa ramowa podpisana przez państwa EAC jest wstępnym dokumentem współpracy z UE, w oparciu o który zostanie przygotowany właściwy tekst umowy EPA.

Państwa Afryki Południowej negocjowały w UE, opierając się na strukturach ugrupowania Południowoafrykańska Wspólnota Rozwoju (Southern African Development Community - SADC). W ich przypadku umowy przejściowe EPA podpisały Botswana, Namibia, Lesotho, Suazi oraz Mozambik. Mimo że rokowania z grupą SADC rozpoczęły się najpóźniej, to w stosunkowo krótkim czasie udało się podpisać ostateczne porozumienia przejściowe EPA ze wszystkimi jej członkami (poza Namibią). Negocjatorzy unijni byli bowiem o wiele bardziej doświadczeni i w związku z tym zagadnienia rozwojowe udało się włączyć do umowy w o wiele szerszym wymiarze niż w przypadku poprzednich umów. ${ }^{30}$

Tymczasowe umowy $\mathrm{w}$ ramach EPA z państwem gotowym na ich przyjęcie $\mathrm{z}$ danego regionu były tak skonstruowane, aby w przyszłości stanowiły wzór dla pozostałych państw. Każde z negocjujących ugrupowań przyjęło na początku rokowań tzw. mapę drogową, a więc harmonogram zadań i celów do osiągnięcia w ściśle określonym czasie. Właściwie w żadnym przypadku nie udało się ich w pełni zrealizować. Sukces był połowiczny. Umowy przejściowe EPA zawierały harmonogram liberalizacji wymiany handlowej obejmujący przede wszystkim produkty przemysłowe.

30 P. Frankowski, I. Słomczyńska, op.cit., s. 147. 
Trudności z podpisaniem porozumienia EPA wynikały z kilku przyczyn:

- państwa afrykańskie krytykowały UE za zbyt szczegółowe negocjacje, które w przeważającej mierze skoncentrowane były na sprawach technicznych;

- strona afrykańska uważała, że UE poświęca kwestiom rozwojowym zbyt mało uwagi, kładąc nacisk przede wszystkim na wymiar handlowy;

- słabe struktury państwowe państw afrykańskich i brak możliwości egzekwowania działań niezgodnych z literą porozumienia;

- niewystarczające przygotowanie negocjatorów afrykańskich;

- przedłużające się rokowania rundy WTO z Doha, której postanowienia miały decydujący wpływ na stopień liberalizacji porozumień handlowych państw AKP z UE;

- konieczność dalszych, pogłębionych negocjacji, szczególnie w dwóch obszarach: dostępu do rynku oraz pomocy rozwojowej.

Dużym problemem w negocjacjach nad porozumieniem EPA jest nakładające się członkostwo w regionalnych organizacjach integracyjnych. Przede wszystkim dotyczy to ugrupowań z Afryki Wschodniej i Południowej (ESA, EAC i SADC), gdzie dochodziło do kilkakrotnej zmiany członkostwa. Generowało to poważne przeszkody w negocjacjach EPA, a dla samych ugrupowań afrykańskich wiązało się z zahamowaniem działalności niektórych $\mathrm{z}$ nich, np. unii celnej w ramach EAC. Trzeba przy tym zaznaczyć, że ugrupowanie to należy do najbardziej zaawansowanych pod względem poziomu instytucjonalizacji. Posiada wspólne organy i instytucje. ${ }^{31} \mathrm{Na}$ uwage zasługuje także ugrupowanie SACU, będące oparciem dla działania południowoafrykańskiej unii celnej, do której należą: Botswana, Lesoto, Suazi, Namibia oraz RPA.

Generalnie w literaturze funkcjonuje opinia, że umowy o wolnym handlu między państwami afrykańskimi i UE nie są w interesie tych pierwszych. Przyjmuje się, że powodem działania UE jest, po pierwsze, chęć ustanowienia porozumienia zgodnego z regułami WTO, a po drugie - promowanie liberalizacji handlu. ${ }^{32}$ Krytycy tworzenia porozumień EPAs twierdzą, że połączenie koncepcji wolnego handlu $\mathrm{z}$ regionalizacją będzie miało negatywne konsekwencje dla państw afrykańskich $\mathrm{z}$ tytułu spadku dochodu $\mathrm{z}$ opłat celnych w granicach $10-30 \% \cdot{ }^{33}$ Ponadto małe i niekonkurencyjne gospodarki mogą stracić na porozumieniu o wolnym handlu z UE, jeśli nie zapewni się im dostatecznej ochrony w postaci systemu specjalnych preferencji.

31 Ibidem, op.cit., s. 146.

32 Ibidem, s. 167.

33 M. McQueen, After Lome' IV: ACP-EU trade preferences in the 21st century, „Intereconomics” September/October 1999, s. 228; P. Watts, Losing Lome: The potential impact of the Commission guidelines on the ACP non-least developed countries, „Review of African Political Economy” 1978, No. 75, s. 52-53. 
Krytyka pod adresem UE nie jest jednak do końca uzasadniona. Działania UE są rozłożone w czasie, a efekty prowadzonych rozmów na temat EPA mało widoczne ze wględu na niedokończony proces negocjacyjny (tymczasowe porozumienia - Interim EPA). Powodem tego są również trwające rokowania w ramach rundy rozwojowej WTO z Doha i brak ostatecznych decyzji dotyczących sposobu i skali liberalizacji. Umowy EPA są przede wszystkim instrumentem promującym rozwój przez liberalizację handlu, która ma przyczynić się do wzrostu gospodarczego, a ten z kolei do redukcji ubóstwa.

\subsection{Republika Południowej Afryki}

Wyjątkiem od formuły negocjacji regionalnych są rokowania UE z RPA. Szczególna pozycja tego państwa ma kilka przyczyn. Po pierwsze, do 1994 roku obowiązywała w nim polityka apartheidu, co skutecznie zniechęcało UE do utrzymywania bliższych kontaktów, po drugie, RPA od początku lat 90. stała się symbolem transformacji w kontekście walki o wartości demokratyczne, po trzecie, państwo to odgrywało ważną rolę w procesie integracji Afryki Południowej, a także miało znaczącą pozycję lidera przemian gospodarczych i społecznych wśród państw Południa.

O odmiennym statusie RPA w kontaktach $z$ UE świadczą następujące fakty. W ramach konwencji z Lomé państwo to posiadało od 1997 roku tzw. członkostwo kwalifikowane, co oznaczało, że miały wobec niego zastosowanie wszystkie postanowienia oprócz części dotyczącej handlu, a więc systemu jednostronnych preferencji handlowych UE oraz członkostwa w Europejskim Funduszu Rozwoju. Poza tym RPA mogło uczestniczyć we wspólnych instytucjach partnerstwa UE-AKP oraz dialogu politycznym. Podobny status utrzymany został w ramach porozumienia z Cotonou. ${ }^{34}$ Bardziej rozwinięty rynek południowoafrykański i zróżnicowana struktura eksportowa nie pozwalały na traktowanie RPA na równi z krajami LDCs. Kraj ten nie mieścił się w unijnej kategorii „państwa rozwijającego się” ze względu na lepsze niż inne państwa afrykańskie wskaźniki makroekonomiczne. Przedstawiciele UE postrzegali RPA jako kraj rozwinięty, niemieszczący się w kategorii typowego członka grupy AKP. ${ }^{35} \mathrm{Z}$ drugiej strony niektóre dane dotyczące poziomu i jakości życia społeczeństwa tego państwa plasowały je w grupie krajów słabo rozwiniętych (np. oficjalna

\footnotetext{
${ }^{34}$ G. Olivier, op.cit., s. 8.

35 RPA to najsilniejsza gospodarka Afryki, wytwarzająca ponad 40\% produkcji przemysłowej kontynentu i posiadająca jego $50 \%$ zdolności nabywczej. PKB wynosi $25 \%$ produktu brutto całego kontynentu. W roku 2012 oczekiwany wzrost GDP 7 to 2,7\%. Wydział Promocji Handlu i Inwestycji w Johannesburgu, http://www.johannesburg.trade.gov.pl/pl/przewodnik/article/detail,143,RPA_-_BRAMA_ DO_AFRYKI.html
} 
stopa bezrobocia wynosi 24\%). UE nie chciała się jednak zgodzić na włączenie RPA do umowy z Lomé w części związanej z handlem ze względu na fakt, że był to program typowo pomocowy, charakteryzujący się wysoką asymetrycznością, gdzie nie było szerokiego pola manewru na zmiany we wzajemnej wymianie handlowej.

Najbardziej korzystnym dla UE rozwiązaniem było ustanowienie z RPA strefy wolnego handlu opartej na wzajemnej liberalizacji. Wprawdzie gospodarka RPA była za słaba na przyjęcie pełnych zobowiązań wynikających z takiej opcji, niemniej w perspektywie czasowej mogło to przyspieszyć i zmobilizować ją do dalszych zmian. Niektórzy wskazują, że odmowa UE w sprawie pełnego włączenia RPA do konwencji z Lomé podyktowana była obawą o napływ konkurencyjnych produktów rolnych i tekstylnych. Uczestnictwo RPA w programie specjalnych preferencji dla LDCs mogło też spowolnić lub zatrzymać proces odchodzenia od polityki protekcjonistycznej i hamować napływ BIZ. Jest to tym bardziej uzasadnione, że na początku lat 90. okazało się, iż cele zawarte w konwencji z Lomé nie zostały w pełni osiągnięte.

UE obawiała się szerokiego dostępu do swojego rynku towarów rolnych i tekstylnych z RPA, które mogły stanowić poważną konkurencję dla produktów unijnych. ${ }^{36}$ Był to jeden z powodów, dla których UE wynegocjowała z RPA w 1998 roku dwustronne porozumienie o handlu, rozwoju i współpracy (Trade, Development and Cooperation Agreement - TDCA). Umowa dotyczyła tych dziedzin, dla których postanowienia konwencji z Lomé, a następnie porozumienia z Cotonou nie miały zastosowania. Według P. Frankowskiego i I. Słomczyńskiej był to „specyficzny dokument, łączący elementy umowy z Cotonou, a także umów EPA [...]. Umowa była $\mathrm{w}$ większym stopniu wyważona i w pełni był w niej widoczny potencjał RPA jako kluczowego aktora regionalnego". ${ }^{37}$

Celem porozumienia TDCA było dążenie do zawarcia strefy wolnego handlu na warunkach zgodnych z regułami WTO. Strony przyjęły harmonogram liberalizacji wymiany handlowej, wyłączając jednak wrażliwe dla obu gospodarek produkty w ramach sektorów rolnictwa i tekstyliów. ${ }^{38}$ Długie i trudne negocjacje nad tekstem porozumienia (TDCA) wiązały się z rokowaniami w sferze rolnictwa, rybołówstwa, oznaczeń i marek handlowych charakterystycznych dla produktów regionalnych, $\mathrm{w}$ tym przede wszystkim wyrobów alkoholowych. ${ }^{39}$ Ostateczny tekst umowy był satysfakcjonujący dla obu stron mimo wyraźniej asymetrii w liberalizacji wymiany

36 Ibidem.

37 Ibidem, s. 149.

38 Szerzej: R. Davies, Forging a New Relationship with the EU, w: The EU-SA Agreemen - South Africa, Southern Africa and the European Union, red. T. Bertelsman-Scott, G. Mills, E. Sidiropoulos, South African Institute for International Affairs, Johannesburg 2000, s. 7-8.

39 G. Olivier, op.cit., s. 18-19. 
handlowej na korzyść RPA oraz niewątpliwej przewagi gospodarczej i technologicznej UE. Strefa wolnego handlu miała być tworzona od 2000 do 2012 roku i obejmować około 90\% całego handlu między partnerami. W przypadku RPA 95\% jej eksportu do UE miało być objętych zerową stawką celną w przeciągu kolejnych dziesięciu lat. Z kolei bezcłowy dostęp produktów UE do rynku RPA dotyczył 86\% towarów i miał mieć miejsce w okresie dwunastu lat. ${ }^{40}$ Pełna liberalizacja dotyczyła produktów przemysłowych oraz rolnych, z zastrzeżeniem wyjątków i wyłączeń dokonanych przez obie strony.

\section{Program „Wszystko oprócz broni”}

Na podstawie programu „Wszystko oprócz broni” (EBA) Unia Europejska przyznaje państwom najmniej rozwiniętym (LDCs) bezcłowy i bezkwotowy dostęp do swojego rynku. Celem powołanego w 2001 roku porozumienia jest rozwój tych krajów przez zwiększenie wymiany handlowej, przede wszystkim za pomocą ekspansji eksportowej.

Efekty działania EBA w początkowych latach wydają się stosunkowo niewielkie. Wstępne badania przeprowadzone m.in. przez Stevensa i Kennana (2001) pokazały ograniczony wpływ nowych regulacji na wymianę handlową państw afrykańskich. Do podobnego wniosku doszedł Cernat i jego jego koledzy (2003), których prognozy wzrostu eksportu oscylowały wokół 0,5\% w stosunku do wartości bazowej. Wyniki ich badań potwierdzone zostały następnie w 2007 roku przez dwójkę badaczy, Babarinde’a i Fabera, którzy stwierdzili, że program EBA nie miał zasadniczego wpływu na zmianę w eksporcie krajów afrykańskich. Od 2001 roku, a więc wprowadzenia w życie programu EBA, następowało stopniowe zmniejszenie udziału eksportu krajów LDCs skierowanego na rynek UE. Jedną z przyczyn jest zmiana dotychczasowego kierunku eksportu AKP na rynki państw wschodzących, przede wszystkim za sprawą rosnącego popytu na ropę naftową i surowce.

Ograniczony wpływ programu EBA na państwa afrykańskie wynika z kilku powodów. Po pierwsze, kraje te mają bardzo niewielkie możliwości wykorzystania preferencji handlowych, które oferuje im UE. Chodzi tu przede wszystkim o wymagania dotyczące stabilności politycznej i makroekonomicznej, przestrzegania zasady "dobrych rządów" czy odpowiedniego działania instytucji gospodarczych. Po drugie, przyczyną są restrykcyjne zapisy dotyczące reguł pochodzenia. Na przykład niewielki

40 Ibidem, s. 20. 
wzrost eksportu ubrań z krajów LDCs wynika z zapisu zabraniającego wykorzystania komponentów pochodzących z najtańszych surowców. ${ }^{41}$ Są jednak wyjątki. Jednym z nich jest eksport cukru, który znacznie zwiększył się dzięki regulacjom zawartym w EBA i osiągnął maksymalny dopuszczalny poziom. ${ }^{42}$

Niektórzy badacze postrzegają program EBA jako instrument mający szerokie zastosowanie w polityce wewnętrznej i zewnętrznej UE. Przede wszystkim jako katalizator zmian w ramach wspólnej polityki rolnej (CAP); jako instrument służący poprawie stosunków z krajami LDCs, a także środek prowadzący do przyjęcia wielostronnego porozumienia $\mathrm{w}$ ramach rundy rozwojowej WTO z Doha. ${ }^{43}$

Jeśli chodzi o pierwszy przypadek, to regulacje programu EBA przyczyniły się do reformy polityki rolnej UE, przede wszystkim w odniesieniu do cukru i ryżu. Perspektywa nieograniczonego dostępu towarów rolnych z państw AKP na rynek UE stała się powodem reformy polityki rolnej w kierunku zwiększenia jej konkurencyjności. Komisja Europejska posłużyła się groźbą otwarcia rynku europejskiego na tańsze produkty z państw LDCs, aby przeprowadzić reformę opartą na redukcji cen. ${ }^{44}$ Program EBA okazał się dobrym argumentem dla zwolenników wprowadzenia zmian. Na początku popierany jedynie przez dyrektoriat ds. handlu, później także przez dyrektoriat ds. rolnictwa. Reforma wspólnej polityki rolnej okazała się konieczna ze względu na rozpoczęty w 2000 roku proces liberalizacji handlu produktami rolnymi w ramach WTO, włączony następnie do agendy rundy rozwojowej z Doha w 2001 roku. Strategia Komisji dotycząca reformy cukru obejmowała obniżenie cen o prawie jedną trzecią, stopniową redukcję bezpośrednich dopłat dla rolników UE oraz kwot produkcyjnych, a jednocześnie zwiększenie importu z krajów AKP $w$ ramach programu EBA. ${ }^{45}$

Handel cukrem między UE i państwami AKP regulowany był przez protokół cukrowy, który ustanowiony został w 1975 roku, a przestał obowiązywać w roku 2009. Na jego podstawie UE importowała z AKP ściśle określone ilości cukru po cenie gwarantowanej. Przeciwni reformie CAP byli więc nie tylko producenci cukru w Europie, ale także państwa AKP, w tym afrykańscy producenci i eksporterzy tego towaru, którzy woleli system oparty na wyższej cenie gwarantowanej i z góry ustalonych kwotach. W zamian za wygasły w 2009 roku protokół cukrowy UE oferowała nieograniczony eksport cukru z AKP po znacznie wyższej cenie obowiązującej na

${ }^{41}$ G. Faber, J. Orbie, Everything But Arms: Much More than Appears at First Sight, ,Journal of Common Market Studies" September 2009, Vol. 47, Issue 4, s. 769.

${ }^{42}$ L. Cernat, L. Laird, S. Monge-Roffarello, L. Turrini, The EU's Everything but Arms Initiative and the LDCs, „WIDER-UNU Discussion Paper” 2003, No. 47, s. 18.

${ }^{43}$ G. Faber, J. Orbie, op.cit., s. 770.

44 Ibidem, s. 775.

45 Ibidem. 
rynku UE. Państwa LDCs domagały się natomiast utrzymania kwot importowych do 2019 roku. Liberalizacja rynku cukru w UE, a więc otwarcie na zewnątrz miało prowadzić do zwiększenia konkurencyjności europejskiego sektora produkcji. Dzięki podjętym reformom sektor rolny w UE miał stać się bardziej zorientowany rynkowo, ale także mniej atrakcyjny jeśli chodzi o import, w tym z krajów AKP. ${ }^{46}$

Biorąc pod uwagę drugą opcję, zakres i skala programu EBA pokrywają się w dużym stopniu z założeniami umowy EPA. Chodzi o członkostwo i kwestie potencjalnych korzyści. Dlatego duża część państw afrykańskich wahała się, czy przyjąć porozumienie EPA w momencie, gdy obowiązywał już program EBA. W przypadku EBA jest to system specjalnych preferencji oferowany wszystkim państwom najmniej rozwiniętym (LDCs) w oparciu o klauzulę umożliwiającą (enabling clause). ${ }^{47}$ Z kolei umowa EPA umożliwia powołanie do życia strefy wolnego handlu, zgodnie z przepisami WTO (art. XXIV GATT). Jakie są jednak korzyści i różnice wynikające z obowiązywania tych dwóch porozumien dla państw, które by je przyjęły? W obu przypadkach chodzi o korzyści, jakie kraje AKP będą miały ze specjalnych preferencji handlowych (EBA) lub bezkwotowego i bezcłowego dostępu do rynków państw wysoko rozwiniętych (EPA). Należy jednak rozgraniczyć korzyści krótkookresowe i długookresowe. W pierwszym przypadku chodzi przede wszystkim o preferencje krótkookresowe. Okres obowiązywania programu EBA jest ograniczony, a poziom i skala preferencji są uwarunkowane sytuacją w UE. W drugim przypadku formuła strefy wolnego handlu wydaje się trwalsza i rozwojowa, a jej funkcjonowanie zależy od obu zaangażowanych stron, nie tylko od UE. Warunkiem są jednak reformy gospodarcze i społeczne w zainteresowanych państwach AKP.

Dotychczas w negocjacjach dotyczących EPA wzięły udział wszystkie państwa AKP zaliczane do grupy najmniej rozwiniętych, jednak do stycznia 2008 roku jedynie dziewięć $\mathrm{z}$ nich zdecydowało się na odstąpienie od EBA na rzecz przyjęcia tymczasowej umowy EPA. ${ }^{48} \mathrm{~W}$ związku z tym większość państw afrykańskich prowadzi wymianę handlową z UE w oparciu o program EBA zamiast regulacji zawartych w EPA. Jaki więc płynie z tego wniosek, skoro od 2002 roku toczyły się intensywne negocjacje między UE i AKP w sprawie EPA i żadnemu państwu z Afryki/ugrupowaniu integracyjnemu nie udało się podpisać właściwego porozumienia? Pewnego

46 W 2005 roku WTO uznało, że instrumenty stosowane na unijnym rynku cukru są niezgodne ze zobowiązaniami wielostronnymi. Chodziło o system krzyżujących się subsydiów, a więc kwestię nieuznawania przez UE reeksportu cukru z państw AKP jako część dozwolonej ilości subsydiowanego cukru $\mathrm{w}$ ramach porozumienia WTO na temat rolnictwa. Dostosowanie do regulacji WTO było jednym z powodów przeprowadzenia reformy Wspólnej Polityki Rolnej.

47 Klauzula umożliwiająca dotyczy krajów rozwijających się i pozwala na odstępstwo od ogólnych zasad WTO w określonym przypadku.

${ }^{48}$ G. Faber, J. Orbie, op.cit., s. 779. 
rodzaju wyjątkiem są tymczasowe umowy EPA, które zawierają jedynie harmonogram liberalizacji wymiany handlowej towarami. Odpowiedzią może być brak porozumienia w ramach toczącej się od 2001 roku rundy WTO, zwanej rozwojową (Doha Development Round). Jest to trzeci z analizowanych przypadków. Burzliwy przebieg negocjacji WTO wynika $z$ trudnych do ustalenia nowych reguł handlowych między państwami członkowskimi należącymi do bogatej Północy a państwami rozwijającymi się i LDCs, określanymi jako kraje Południa. Impas w negocjacjach wielostronnych WTO ma bezpośredni wpływ na rokowania regionalne i porozumienia dwustronne. Dlatego też brak ustaleń co do stopnia i metody liberalizacji handlu na poziomie wielostronnym WTO rzutuje na poziom regionalny. Ustalenia w ramach ugrupowań regionalnych i bilateralnych powinny być zgodne z ogólnymi zasadami i regułami obowiązującymi w ramach WTO. Stąd wynikają opóźnienia w przyjmowaniu porozumień o partnerstwie gospodarczym między UE i państwami AKP.

Bez wątpienia działania podejmowanie przez UE i WTO wzajemnie się uzupełniają. Wskazują na to następujące czynniki. Po pierwsze, brak większych sukcesów w zawieraniu porozumień o partnerstwie gospodarczym między UE i AKP jest skutkiem impasu w rokowaniach WTO. Zanim jednak do tego doszło, uruchomiony w 2001 roku przez UE program EBA przyczynił się do wzrostu poparcia wśród państw LDCs dla nowej rundy WTO. Za sprawą EBA wizerunek UE i jej polityki rozwojowej znacznie się poprawil, a także „uwiarygodnił” jej poparcie dla rundy rozwojowej WTO. Przykład ten pokazuje więc skalę i wpływ działania UE na arenie międzynarodowej. Uruchamiając specjalny program preferencyjny dla państw LDCs, Unia przyczyniła się do zdobycia ich poparcia dla negocjacji WTO. Rozpoczęcie rundy WTO w listopadzie 2001 roku należało do głównych interesów UE. Udało się więc uzyskać poparcie najbardziej niezadowolonych z przebiegu dotychczasowej liberalizacji członków WTO.

Jednakże efekty działania EBA dla krajów LDCs, w obliczu trwających negocjacji rundy WTO, okazały się przeciwne do zamierzonych. Wiele krajów afrykańskich uznało bowiem, że pogłębiająca się liberalizacja będzie miała negatywny skutek dla ich gospodarek, ograniczy bowiem ich margines preferencji w porównaniu z innymi krajami rozwijającymi się. Umowa EBA natomiast zakłada preferencyjny dostęp do rynku UE jedynie dla krajów LDCs, czego nie można założyć w umowie wielostronnej WTO. Korzystając więc z systemu preferencji w ramach EBA, wiele z państw AKP straciło zainteresowanie zakończeniem negocjacji rundy z Doha. Potencjalne korzyści z porozumienia ramowego WTO okazały się mniejsze niż krótkookresowe zyski wynikające z programu EBA. Należy dodać, że UE jest głównym partnerem handlowym większości krajów należących do AKP. 
Chcąc odwrócić niekorzystny dla siebie kierunek zmian, Unia zaangażowała się w przekonanie państw LDCs do kontynuacji rokowań wielostronnych. Dzięki UE udało się przyjąć w ramach WTO zobowiązanie państw członkowskich do ustanowienia specjalnego programu na wzór EBA. W grudniu 2005 roku na spotkaniu ministerialnym w Hongkongu ustalono przyjęcie podobnego programu, tyle że o zasięgu światowym. ${ }^{49}$ Państwa wysoko rozwinięte oraz rozwijające się (te, które będą w stanie to zrobić) zapowiedziały ustanowienie bezcłowego i bezkwotowego dostępu do swoich rynków dla towarów z krajów LDCs. Oczywiście pojawiły się propozycje wprowadzenia pewnych wyjątków, m.in. możliwości wyłączenia do 3\% linii taryfowych. W rezultacie, już pod koniec 2008 roku duża część państw LDCs ponownie wyraziła swoje zainteresowanie jak najszybszym zakończeniem rokowań rundy z Doha. Pojawiła się bowiem realna perspektywa otworzenia nowych rynków zbytu dla ich towarów.

Rozwiązanie przyjęte w Europie odnośnie do rozwoju relacji handlowych z krajami najmniej rozwiniętymi stało się wzorem do naśladowania w ramach WTO. Program EBA nie tylko przyczynił się do powołania rundy z Doha w 2001 roku, ale może także okazać się punktem zwrotnym w negocjacjach wielostronnych i przyczynić się do pomyślnego zakończenia rokowań wielostronnych. Dzięki szerokiej kampanii UE na rzecz programu EBA pomysł ustanowienia nowych relacji z krajami najbiedniejszymi, w oparciu o zasadę bezłowego i bezwotowego dostępu do rynku, przyjęty został także przez WTO. Prowadzi to do wniosku o uniwersalizacji pewnych rozwiązań w sferze handlu międzynarodowego, prowadzeniu spójnej i zgodnej polityki na poziomie regionalnym i globalnym. Jest to jeden z niewielu przykładów tego rodzaju działań, które udało się osiągnąć w ostatniej dekadzie. Program o ograniczonym zasięgu i niewielkim wpływie gospodarczym (EBA) stał się katalizatorem zmian w UE, w ramach wspólnej polityki rolnej, a także na poziomie globalnym, w WTO. Dzięki programowi udało się przekonać do rozwiązań liberalizacyjnych te państwa, które w największym stopniu były im przeciwne. Oferując „marchewkę" w postaci perspektywy dostępu do rynków państw rozwiniętych, użyto także „kija”, którym może być odstąpienie od preferencji udzielanych w ramach EBA na rynku UE oraz na poziomie globalnym.

Program EBA ma znaczący wpływ na zakres proponowanej umowy EPA między UE i AKP. Nie tylko stanowi on alternatywę dla państw LDCs AKP, ale także jest punktem odniesienia dla krajów niezaliczanych do grupy najmniej rozwiniętych. Chodzi przede wszystkim o porównanie stopnia koncesji taryfowych oferowanych przez UE w ramach porozumień EPA. Jest to o tyle znaczące, że część państw AKP

49 WTO ministerial declaration, Hong Kong, December 18, 2005. 
nie należy do grupy najmniej rozwiniętych (LDCs), do których skierowany jest program EBA. Propozycja objęcia bezcłowym i bezkwotowym dostępem do rynku UE wszystkich państw AKP przyjmujących umowę EPA, tak jak ma to miejsce w programie EBA, była nie do zaakceptowania dla członków UE (głównie Francji, Hiszpanii, Portugalii i Cypru). W miarę upływu czasu i z powodu nikłych rezultatów dotyczących negocjacji porozumienia EPA państwa członkowskie UE zdecydowały się rozszerzyć dostęp do swojego rynku na wszystkie kraje AKP, ale z wyjątkami. Przyjęto okresy przejściowe na obrót trzema artykułami rolnymi: cukrem, bananami i ryżem.

Konsekwencją otwarcia rynku UE dla towarów ze wszystkich państw AKP jest, po pierwsze, zgodność z regułami WTO, po drugie zaś osłabienie specjalnej pozycji państw AKP w polityce handlowej UE. Oznacza to normalizację wzajemnych stosunków, a więc oparcie wymiany handlowej na powszechnie przyjętych regułach obowiązujących we WTO.

\section{Spójność w polityce zewnętrznej UE}

Relacje między Wspólnotą a państwami afrykańskimi cechuje duża różnorodność, co wynika m.in. z odmiennych interesów niektórych państw członkowskich UE. W początkowym okresie rozwijania współpracy WE-Afryka decydującą rolę odgrywały Francja oraz Wielka Brytania, posiadające specjalne stosunki polityczne $\mathrm{i}$ handlowe $\mathrm{z}$ byłymi koloniami afrykańskimi. Francja była inicjatorem nowego rozdziału we wzajemnych stosunkach, włączając zapisy o specjalnych relacjach między Afryką i Europą do Traktatu rzymskiego (1957). W związku z tym państwo to zapewniło sobie decydujący wpływ na politykę europejską w zakresie relacji z kontynentem afrykańskim, m.in. przez kluczowe stanowiska i liczbę urzędników pracujących w departamentach Komisji Europejskiej odpowiedzialnych za kwestie rozwojowe. Z kolei Wielka Brytania prowadziła politykę będącą wypadkową strategii francuskiej i podejścia reprezentowanego przez innych wpływowych członków UE - Niemiec i Holandii. Z jednej strony rząd londyński popierał politykę francuską, co dawało mu możliwość utrwalenia specjalnych stosunków z byłymi koloniami i wpływu na ich działanie, z drugiej zaś opierał się w swoich relacjach na zasadzie wolnego handlu, co bliższe było stanowisku niemiecko-holenderskiemu. ${ }^{50}$

Podziały między państwami członkowskimi w kontekście negocjowania umów o partnerstwie gospodarczym (EPA) były wynikiem różnic co do wizji stosunków

50 P. Frankowski, I. Słomczyńska, op.cit., s. 54-55. 
europejsko-afrykańskich. Podobnie było przy rokowaniach nad przyjęciem konwencji z Lomé. Na poziomie wspólnotowym propozycje Dyrektoriatu Generalnego ds. Handlu były krytykowane przez Dyrektoriat ds. Rolnictwa, a oba podejścia nie były tożsame z wizją prezentowaną przez Dyrektoriat ds. Rozwoju. ${ }^{51}$ Podziały te wynikały z różnic między stanowiskami poszczególnych państw członkowskich, kierujących się odmiennymi interesami. Przede wszystkim dotyczyło to zasady wolnego handlu versus polityki protekcjonistycznej. Zwolennikami pierwszej opcji są Niemcy, Holandia, a także Wielka Brytania i państwa skandynawskie, popierane przez Komisję. Z kolei politykę nastawioną bardziej protekcjonistycznie są skłonne prowadzić Francja, Włochy, Hiszpania, Portugalia i Grecja. Wyraża się to przede wszystkim w ich stanowisku wobec liberalizacji wymiany handlowej w dziedzinie rolnictwa i tekstyliów.

Na tej podstawie zarysowuje się generalny podział wśród członków UE na grupę zwaną „regionalistami” i „globalistami”. Do pierwszej z nich zalicza się państwa, które ze względu na swoje polityczne i historyczne związki z byłymi koloniami dążą do zachowania specjalnych stosunków. Z kolei „globaliści” chcą poszerzenia zewnętrznych działań UE, ze szczególnym uwzględnieniem sytuacji krajów LDCs. ${ }^{52}$ Opcję tę popierają Wielka Brytania i państwa skandynawskie, natomiast Francja, Hiszpania i Włochy wskazują na utratę korzyści komparatywnych dla krajów AKP z powodu ograniczenia ich preferencyjnego traktowania i postępującej liberalizacji. Obawa o kraje AKP jest jednak w rzeczywistości troską o utratę własnej pozycji konkurencyjnej względem tańszych produktów rolnych z krajów afrykańskich, z którymi musieliby konkurować dotowani $z$ budżetu UE europejscy producenci cukru, bananów czy ryżu. Zmiany będące następstwem wprowadzenia w życie „kontrolowanej” liberalizacji zewnętrznej UE i krajów AKP będą prowadziły do wzajemnych przeobrażeń. W przypadku UE będzie to reforma polityki rolnej UE oraz systemu pomocy dla państw rozwijających się i LDCs. Z kolei kraje AKP staną przed koniecznością restrukturyzacji sektora rolnego i poprawy struktury eksportu.

Polityka UE wobec Afryki składa się przynajmniej z trzech poddziedzin o różnej strukturze instytucjonalnej oraz odmiennych regułach podejmowania decyzji. Inicjatywy polityczne są formułowane, a decyzje ich dotyczące podejmowane w bardziej lub mniej autonomicznych sektorach, które charakteryzują się istnieniem swoich specyficznych, interesów, procedur i reguł. Na przykład w ramach WPZiB pomoc rozwojowa i polityka handlowa to dwie odseparowane dziedziny polityki zagranicznej UE, które w praktyce, zgodnie naczelnym celem zachowania spójności, powinny wzajemnie się uzupełniać i współgrać. ${ }^{33}$ Sektor pomocy rozwojowej

51 G. Faber, J. Orbie, op.cit., s. 772.

52 Ibidem.

53 G.R. Olsen, op.cit., s. 3. 
przez lata posiadał daleko idącą autonomię w ramach polityki UE, która w ostatniej dekadzie nieco osłabła ze względu na toczący się konflikt interesów między pomocą rozwojową w ramach państw członkowskich a wspólnotową polityką pomocową.

W tym miejscu warto nieco bliżej przyjrzeć się ocenom działania dotyczącym polityki rozwojowej UE i wspólnej polityki handlowej.

Kontakty między WE a państwami AKP do końca lat 90. opierały się właśnie na wytycznych w ramach tej polityki. Współpraca na rzecz rozwoju/polityka rozwojowa należy do wspólnej kompetencji UE i państw członkowskich. W Traktacie z Maastricht (w tytule XVII) oraz Traktacie amsterdamskim wzmocnione zostały jej podstawy prawne. Zgodnie z art. 177-181 Traktatu UE polityka rozwojowa jest komplementarna w stosunku do innych rodzajów polityki prowadzonej przez UE. Jest ona jednak krytykowana, a jednym z głównych zarzutów jest brak spójności $\mathrm{z}$ innymi rodzajami polityki UE, $\mathrm{w}$ szczególności handlu, rolnictwa i ochrony środowiska. Słabą ocenę dotyczącą efektywności prowadzonej polityki w dziedzinie rozwoju wydały nie tylko państwa beneficjenci, ale także Parlament Europejski ${ }^{54}$ oraz OECD. W przeglądzie OECD na temat pomocy rozwojowej UE wyraźnie podkreślono „brak spójności i zgodności w działaniach UE dotyczących rozwoju, które zawarte zostały w strategii, stanowiskach na temat współpracy rozwojowej, a także prowadzonej polityki związanej ze stabilizacją makroekonomiczną, podejściem sektorowym, dotyczącej zamówień publicznych, identyfikacji i wdrażania programów oraz ich oceny". ${ }^{55}$ Ponadto wskazano na nieistnienie spójnej definicji pojęcia ubóstwa, co prowadzi do braku zrozumienia i licznych błędów w podejściu do kwestii pomocy rozwojowej. Wskaźnik ubóstwa mierzony kwotą jednego dolara dziennie nie jest wystarczającym miernikiem. Podważona została także europejska koncepcja „dobrego rządzenia” (good governance), uznana za mało przejrzystą i budzącą wiele wątpliwości. ${ }^{56}$ Dla przypomnienia, jest to jedna z podstawowych zasad, którymi UE kieruje się w związku z przyznawaniem pomocy rozwojowej.

Doświadczenia $\mathrm{z}$ prowadzenia polityki handlowej wobec państw afrykańskich w połowie lat 90 . wskazywały, że dotychczasowe działania UE były nieskuteczne. System jednostronnych preferencji ze strony UE nie spełnił swoich oczekiwań, a nawet pogłębił ówczesne dysproporcje rozwojowe. W wydanej w 1996 roku „Zielonej księdze” stwierdzono, że kraje afrykańskie nie zdołały zintegrować się

\footnotetext{
54 EU development policy needs joined-up thinking, say MEPs, October 25, 2012, http://www. europarl.europa.eu/news/pl/pressroom/content/20121024IPR54371/html/EU-development -policy-needs-joined-up-thinking-say-MEPs

55 EU development co-operation: improving but still cumbersome, OECD, April 24, 2012, http://www. oecd.org/newsroom/eudevelopmentco-operationimprovingbutstillcumbersome.htm

56 Peer reviews in development cooperation, OECD, March 28, 2012, http://www.oecd.org/dac/ peerreviewsofdacmembers/peerreviewsindevelopmentco-operation.htm
} 
z gospodarką światową mimo kilkudziesięciu lat preferencyjnego mechanizmu oferowanego im przez państwa WE w ramach konwencji z Lomé. Wyraźnym tego sygnałem był malejący udział państw afrykańskich w światowej i unijnej wymianie handlowej. ${ }^{57}$ Dlatego w 1998 roku Komisja Europejska rozpoczęła negocjacje w sprawie nowego typu umów gospodarczych z kontynentem afrykańskim, które miały przybrać formę porozumień o partnerstwie gospodarczym (EPAs).

Podział na sektory w ramach danej polityki UE prowadzi, zdaniem G.E. Olsena, do tworzenia specyficznych interesów danego sektora, co w konsekwencji powoduje zatarcie wspólnych interesów i ograniczenie ryzyka wyłącznie do danej polityki i sektora. Zdaniem tego samego autora jest to podstawowy powód braku efektywności w niektórych działaniach zewnętrznych prowadzonych przez UE. ${ }^{58}$ Podejście sektorowe, będące następstwem podziału na poszczególne rodzaje polityki, utrudnia prowadzenie całościowej i spójnej polityki UE wobec określonego partnera, co wiąże się z wieloma problemami. Po pierwsze, działania mogą się dublować, powodując podwójne koszty dla obu stron. Po drugie, wzajemnie nakładające się cele i zadania mogą być trudne do weryfikacji, a kontrola ich prawidłowego wykonania, a co za tym idzie odpowiedzialność rozmywa się. Po trzecie, w gąszczu podobnych celów i interesów trudno osiągnąć zamierzone wyniki. Końcowe efekty są trudne do uchwycenia i przeradzają się w ogólnikowe stwierdzenia. Ta swego rodzaju „sektoryzacja" polityki i procesu podejmowania decyzji może hamować lub ograniczać możliwości stosowania różnych instrumentów polityki zagranicznej w sposób spójny i skoordynowany. ${ }^{59}$

Skuteczność polityki zagranicznej UE zależna jest od dwóch czynników. Po pierwsze, jest to kwestia spójności i zgodności między różnymi instrumentami polityki zewnętrznej UE a polityczną wolą ich użycia. Spójność horyzontalna UE to zachowanie zgodności $\mathrm{w}$ działaniu między poszczególnymi rodzajami polityki UE. Wymagana jest zatem wiedza dotycząca celów i zadań w ramach danej inicjatywy politycznej, aby nie była ona z gruntu sprzeczna z celami innych. Odmiennym wymiarem spójności politycznej jest „zgodność instytucjonalna”. Jest to zasada mająca na celu przeciwdziałanie występowaniu zróżnicowanych procedur i odmiennych interesów. Niezgodność w tym przypadku mogłaby wynikać z różnego podejścia do tego samego problemu czy osiągania różnych celów przez innych aktorów.

57 Commission Green Paper on Relations between the European Union and the ACP Countries on the Eve of the 21st Century: Challenges and Options for a New Partnership, Commission of the European Communities, Brussels, November 14, 1996.

58 G.R. Olsen, op.cit., s. 3.

59 Ibidem, s. 4. 
Jednakże najważniejszym czynnikiem decydującym o skuteczności jest wola polityczna, a więc zgoda na wykorzystanie wszystkich możliwych instrumentów. Cele polityki WPZiB i wynikające stąd interesy są wynikiem długotrwałego procesu politycznego, angażującego licznych aktorów, począwszy od instytucji UE, grup lobbingowych i organizacji pozarządowych po rządy państw członkowskich.

Spójność polityki zewnętrznej wobec kontynentu afrykańskiego należy rozpatrywać w trzech wymiarach. Pierwszym jest spójność polityki prowadzonej przez instytucje UE, drugim - spójność celów i interesów wynikających z poszczególnych obszarów działania UE, trzecim zaś spójność na poziomie UE oraz polityki narodowej państw członkowskich. ${ }^{60}$ Potrzeba integracji różnych instrumentów polityki zewnętrznej UE wobec Afryki wynika przynajmniej z dwóch czynników. Pierwszym jest ambicja odgrywania przez Wspólnotę Europejską od momentu powstania w 1958 roku roli ważnego i silnego uczestnika stosunków międzynarodowych. Drugim - skomplikowany i długotrwały proces tworzenia polityki i podejmowania decyzji w ramach UE, który utrudnia, a nawet blokuje zaspokojenie tej ambicji. Segmentacja polityki i proces decyzyjny blisko powiązane z interesami danego sektora mogą wyjaśniać, według G.R. Olsena, niedociągnięcia związane ze skutecznością polityki zagranicznej UE. ${ }^{61}$

\section{Zakończenie}

Relacje między Unią Europejską i Afryką znajdują się obecnie na nowym etapie rozwoju. Wyznacznikiem tego podejścia jest budowa umów nowej generacji opartych na współpracy gospodarczej (EPA). Negocjacje nad przyjęciem porozumień trwają, co oznacza, że stosunki znajdują się w fazie rozwoju i dostosowywania do nowych uwarunkowań wewnętrznych i międzynarodowych. Powodów zmian jest kilka. Po pierwsze, poprzedni system wymiany handlowej oparty na konwencjach z Lomé był niezgodny ze zobowiązaniami UE w ramach WTO. Wprawdzie Wspólnota uzyskała zwolnienie WTO, które zezwalało na odstępstwa od regulacji w określonym czasie, liczono się jednak z ich zakończeniem. Po drugie, celem UE zgodnie $\mathrm{z}$ art. 130 Traktatu z Maastricht jest stopniowa integracja krajów rozwijających się z gospodarką światową oraz nacisk na zwalczanie ubóstwa i rozwój. Skutkiem

\footnotetext{
60 P. Frankowski, I. Słomczyńska, op.cit., s. 23.
}

61 G.R. Olsen, op.cit., s. 2. 
tego jest wsparcie dla integracji regionalnej państw afrykańskich oraz liberalizacja wymiany z zachowaniem systemu preferencji dla najbiedniejszych (LDCs).

Negocjacje w sprawie porozumienia o partnerstwie gospodarczym między UE a państwami Afryki Subsaharyjskiej prowadzone są w oparciu o zapisy umowy z Cotonou (2000). Opierają się one na specjalnej formule „partnerstwa” wypracowanej w konwencjach z Lomé, a następnie strategii UE-AKP. Nowa generacja umów typu EPA ma za zadanie „znormalizować” uprzywilejowane partnerstwo z krajami AKP i doprowadzić do stopniowego włączenia tych krajów do głównego nurtu gospodarki światowej. Chodzi więc o objęcie krajów AKP tymi samymi regułami handlu międzynarodowego, które obowiązują pozostałych członków WTO, oczywiście po okresie przejściowym i z zachowaniem pewnych wyjątków dla państw najmniej rozwiniętych. Oznacza to oparcie wzajemnych stosunków handlowych na regułach obowiązujących w ramach WTO dotyczących zawierania i funkcjonowania stref wolnego handlu i unii celnych. Poprzednie porozumienia między UE i AKP nie stosowały się do tego typu reguł, a wymiana handlowa między nimi opierała się na jednostronnie gwarantowanych preferencjach ze strony UE.

W obliczu kończącego się terminu obowiązywania porozumienia z Cotonou (2008) państwa afrykańskie stanęły przed wyborem dotyczącym przyszłych relacji z UE. Pierwszą z opcji jest przyjęcie tymczasowej umowy w ramach EPA, drugą - prowadzenie wymiany handlowej z UE na podstawie systemu ogólnych preferencji (GSP), a trzecią - w oparciu o preferencyjny program pt. „Wszystko oprócz broni” („Everything but Arms” - EBA). Z powodu potencjalnie większych korzyści państwa afrykańskie powinny podjąć rokowania w sprawie porozumienia EPA, chociaż wymierne zyski w krótkim okresie gwarantuje im porozumienie EBA.

Mimo powszechnej krytyki działań podejmowanych przez UE wobec Afryki Subsaharyjskiej można dostrzec pewne oznaki sukcesu, chociaż nie są one tak widoczne jak w przypadku porażek. Okazuje się więc, że wspólnie podzielany interes UE dotyczący wielostronnej liberalizacji handlu i pomocy rozwojowej dla państw najbiedniejszych może być jednak skutecznie realizowany, i to nie tylko w oparciu o instrumenty dostępne na poziomie wspólnoty, ale także w ramach WTO. Przykładem jest unijny program „Wszystko oprócz broni”. Z jednej strony przyczynił się on do uzyskania poparcia państw LDC dla uruchomienia rudny WTO w 2001 roku, z drugiej zaś stał się wzorem do naśladowania i przyjęcia podobnych rozwiązań we WTO. Państwa najmniej rozwinięte, mimo swojej słabej pozycji gospodarczej, stanowią silną grupę nacisku ze względu na swoją liczebność, a zatem poważną siłę przetargową w negocjacjach WTO. Są one więc swego rodzaju języczkiem u wagi jeśli chodzi o przełom w rokowaniach rundy z Doha. Przekonanie ich do rozwiązań liberalizacyjnych może okazać się decydującym czynnikiem dla przyjęcia ostatecznego porozumienia. Rola 
UE w koordynowaniu działań zmierzających do tego celu jest w tym układzie bezsprzeczna, jednakże na ostateczne efekty trzeba będzie jeszcze poczekać do zakończenia rundy WTO z Doha.

\section{External institutionalization of EU: case study of Sub-Saharan Africa}

Institutionalization of relations with Sub-Saharan Africa states is one of approaches used to include those states in main currents of world economy. The African states will benefit because new markets for their exports will open which will increase the speed of reform of their political systems and economies. EU will benefit because better overall situation of the African states will help in development of stable multilateral relations. In this paper I analyze the EU Sub-Saharan states relations as an example of institutionalization understood as development of legal and institutional solutions that shape international relations. In this context institutionalization is an instrument that enhances systematic change which in turn leads to transformation of particular states and regions. In the paper I try to answer the question: is the declared level of integration of different instruments of EU foreign policy identical with the reality vis-a-vis the states of Africa.

\section{Внешняя институционализация ЕС на примере Африки к югу от Сахары}

Процесс институционализации отношений со странами Африки южнее Сахары является одним из способов включения этих стран в основное русло развития мировой экономики, что должно привести к взаимной выгоде. Это позволит африканским государствам участвовать в глобальной системе, открыть рынки для экспорта своих товаров и ускорит реструктуризацию экономики и политических систем. Со стороны ЕС, перспектива участия африканских стран в мировой экономической системе будет способствовать улучшению их экономической, политической и социальной ситуации, и, следовательно, повлияет на нормализацию взаимных контактов путём сокращения системы специальных преференций. Целью исследования является показать, на примере отношений ЕС - Африка южнее Сахары, процесс институционализации, понимаемой как сеть правовых и институциональных рамок, которые определяют международные отношения. 
В этом контексте, это инструмент для ускорения определенных системных решений, которые должны привести к изменениям в странах и регионах им обнятых. Эти изменения касаются правил и поведения в государствах, куда направлены эти мероприятия, в этом случае Африки южнее Сахары, а также в этих субъектах, которые иницируют эти действия (ЕС). Это исследование становится попыткой показать, является ли и в какой степени декларированный уровень интеграции разных инструментов внешней политики ЕС совпадает с реально предпринятыми по отношению к африканским государствам действиями. 